UDC 027.7:005.745

KOLESNYKOVA T. O.

Scientific and Technical Library, Dnipro National University of Railway Transport named after Academician V. Lazaryan (Dnipro, Ukraine), e-mail: chief.library@gmail.com, ORCID 0000-0002-4603-4375

\title{
CONFERENCE TIME IN THE LIBRARY AND INFORMATION SCIENCES. PART 2: ANALYSIS OF PUBLICATION ACTIVITY AND CITATION
}

Objective. The second part "Conference time in the library and information sciences" of the study is aimed at conducting a bibliometric analysis of the publication activity and citation of the authors presenting their papers at international conferences indexed in Scopus and/or Web of Science (CC). Methods. Bibliometric analysis of publications that are Conference proceeding ("proceedings paper" and/or "conference paper") was carried out using the Scopus and Web of Science (CC) citation databases. Using a comparative analysis, the obtained data, covering the "conference paper"/"proceedings paper" publication type for all years of their reflection in each of the databases, as well as in chronological frames from 2016 to 01.06 .2020 were studied. Results. Analysis of the publication activity of LIS university (academic) researchers shows that Scopus $(n=4561)$ contains more documents than WoS database $(n=4145)$. The growth of Open Access (OA) documents in both databases is significant since 2000. But the period 2016-01.06.2020 demonstrates a slight dominance of the number of OA publications in Scopus ( $\mathrm{n}=192)$ compared to WoS ( $\mathrm{n}=185$ ). Distribution data by authors, universities, countries, knowledge areas were also obtained. Citation analysis shows poor results on both bases, which may be due to the focus of conferences on rapidly changing topics. Conclusions. Showing the relatively low LIS coverage in university research, as well as low citation rates, this paper demonstrates that LIS researchers/practitioners need to create more quality publications to be recognized as an important area. The author hopes that this work will generate great research interest in the field of LIS and understanding the great value of Conference proceeding as a publication containing original/primary research results.

Keywords: library and information science; conference; conference proceeding; proceedings paper; conference paper; university library; publication activity; bibliometric analysis; citation

\section{Introduction}

This work continues the research on "Conference time in the library and information sciences. Part 1: Conference proceedings and proceedings (conference) paper". In the first part we: 1) acquired new information on alternative conference formats, including in the field of Library and Information Science (LIS), which have arisen as a result of the COVID-19 pandemic and restrictions on physical communication; 2) clarified the role in the scientific ecosystem of such a communication channel as Conference proceeding, as well as the concepts of "proceedings paper" and "conference paper."

When clarifying, including the value of the Conference proceeding publication type, I would like to draw attention to the 7 th item. The value of the Conference proceeding lies in the following facts:

1. This format helps authors of primary research in rapidly developing fields of science to get their research work to the global community faster than traditional journals.

2. Provision of reports on scientific meetings and obtaining snapshots of early-stage research that may later appear in full research papers.

3. For scientists just beginning their careers, the papers offer what may be their first experience in publishing peer-reviewed works. 
4. Small scientific communities and scientists of those countries that currently have a low publication and impact level in international scientific journals.

5. Most conferences use only one (or two) review/revision cycles due to deadlines, which is a softer variant than traditional journals.

6. They give an incentive for personal growth and help to overcome the psychological barrier for those researchers who are recognized scientists in their countries/regions, but did not have the incentive and opportunity to publish in foreign journals/conference proceedings because of the country's internal politics.

7. Conference proceeding papers, like journal articles and other types of publications, also form an important scientific field in which bibliometric tools can be used to evaluate various outcomes, through which it has attracted the attention of scholars in various disciplines.

It is the 7th item in the presented list of values that became the most significant for the author, as it is devoted to measuring the size of the world flow of such a publication type as Conference proceeding, reflecting various aspects of the library and information sphere, and its qualitative characteristics.

\section{Literature analysis}

Research work in the field of Library and Information Science (LIS) reflects progress in LIS profession. To determine its strengths and weaknesses, LIS research productivity analysis is carried out. One of the main objectives of scientometric research is to evaluate the scientific result and impact of various subject areas, countries, authors, institutions, etc. (Erfanmanesh, Didegah, \& Omidvar, 2010).

M. Jokić (2020), continuing the subject of bibliometric research in the field of LIS, talks about the publishing activity, visibility, impact, the scientific interaction of authors, as well as research trends.

The scientists in the field of LIS that examine the issues related to the place of LISpublications in the knowledge management process (Ahmad, JianMing, \& Rafi, 2019) note the insufficient activities by researchers. Thus, according to a study by N. K. Agarwal \& M. A. Islam (2018), the number of papers in the leading journals associated with LIS is very limited.

The peculiarity of LIS university researchers should be emphasized. In addition to research focused only on the library science, there is a need for research in various disciplines relevant to their institutions (Borrego, Ardanuy, \& Urbano, 2018; Kolesnykova, Pominova, \& Kolesnykov, 2016; Kolesnykova, Matveyeva, Manashkin, \& Mìshchenko, 2019; Dash, Sahoo, \& Mohanty, 2015). At the same time, scientific cooperation with teachers and scientists, leading to the coauthorship of scientific results, is, firstly, one of the possible ways to demonstrate the compliance of the library with the institution's mission; secondly, participation in research improves librarians' skills in providing services for research support (Borrego, Ardanuy, \& Urbano, 2018).

Á. Borrego and S. Pinfield (2020) examine the incentives for librarian participation, the benefits that are believed to be derived from partnerships with educators, and the challenges they face.

In addition, the experience of librarians in the field of bibliometrics can be used to help individual researchers, departments, faculties prove their scientific contribution to success at their universities (Kolesnykova, Pominova, \& Kolesnykov, 2016; Kolesnykova, Matveyeva, Manashkin, \& Mìshchenko, 2019).

The current trend of publishing and presenting the most important research papers indicates that authors and their institutions prefer three types of publications of high-quality papers: 1) national journals with an international reputation; 2) the best international journals generally 
recognized in the field of research; 3) the best national and international conferences and their materials - Conference proceeding.

M. A. Anwar and H. Saeed (1999) in a bibliometric study have shown that the "journal article" publication type produced by Pakistani authors accounts for $90.4 \%$ of citations, with the majority of journals published in the United States.

Fifteen years later, Jabeen, Mun., Yun, L., Rafiq, M. and Jabeen, Mis. (2015) conducted a quantitative study to learn about the growth and trends of LIS publications on a global scale. They studied those documents that are indexed in the core collection of ISI Web of Science (WoS) database. "Journal articles" have also been identified as the most popular type of publication among LIS researchers.

At the same time, when analyzing the papers included in the Library Assessment Conference (LAC) materials from 2006 to 2014, N. K. Dash, J. Sahoo \& B. Mohanty (2015) emphasize that the number of studies has been constantly increasing, with most of the papers written by one, two, or three authors, which is approximately $40 \%, 33 \%$, and $15 \%$, respectively.

M. Jokic (2020), examining the subject of conference proceedings classification in WoS/Scopus, emphasizes that they can be presented as peer-reviewed journals in the journal category, or, in fact, as Conference Proceeding, or Book Series. But, in any case, their impact factor in these databases are not available (IOPScience, 2020). However, due to indexing, it is possible to track the impact of proceedings papers, authors and conference series.

Another feature of conference proceedings is that their papers become outdated (i.e., no longer attracting new citations) much earlier than the journal articles (Lisée, Larivière, \& Archambault, 2008). Possibly, this is due to the fact that the conferences are more focused on rapidly changing topics.

Borja González-Albo \& María Bordons (2011) came to an interesting conclusion during the case study of the potential differences between standard journal articles and proceedings papers in journals based on the Web of Science data in the field of Library and Information Science. It shows that "proceedings paper in journals" are similar to "standard journal articles" in structure but they have a less rigorous review process, they are published faster, they demonstrate a lower impact (i.e. citation level).

Despite the fact that Scopus and Web of Science databases for citation counting started to index conference proceedings by around the mid-2000s (De Sutter \& Van Den Oord, 2012), there are clearly significant lacunae.

\section{$\operatorname{Aims}$}

The study aims to conduct a bibliometric analysis of the publication activity and citation of authors presenting their papers at international conferences indexed in Scopus and/or Web of Science (CC).

\section{Methods}

Bibliometric analysis of publications that are Conference proceeding ("proceedings paper" and/or "conference paper") was carried out using Scopus and Web of Science (CC) citation databases.

The data were collected in two stages according to the keywords in the document title, brief description (abstracts), keywords. At the first stage, the key phrase university librar* was used. At 
the second stage, the search was limited by the keywords "university library" AND "academic library".

Publication type: "conference paper" (in Scopus) and "proceedings paper" (in Web of Science). The language of publications was not specified.

Using the comparative analysis, the obtained data of Scopus and Web of Science (CC) covering the "conference paper"/"proceedings paper" publication type for all years of their reflection in each of the databases were studied, as well as in the chronological framework from 2016 to 01.06 .2020 .

In addition to the total number of documents, Open Access and Other access type was specified. The author was interested in document distribution analysis presented by knowledge areas in terms of highlighting top subjects.

In order to clarify the publication activity of authors from Eastern European countries, a search and quantitative analysis of publications by countries/territories was also performed.

The information analysis about the most cited authors was carried out in two stages. At the first stage, the data on the world LIS leaders were specified, at the second - the leaders of the Eastern Europe countries.

The author was also interested in top research subjects in the field of Library and Information Science.

From the author's point of view, the use of the mixed methods in this work can help determine the trends and directions of research in the field of Library and Information Science. Results may be relevant to future research and decision-making.

\section{Results}

Scopus and Web of Science databases were used to study an array of conference papers and proceedings papers, reflecting various research aspects of university libraries and librarians.

The results of the publication activity analysis of LIS university researchers (see Table 1) show that Scopus $(n=\mathbf{4 5 6 1})$ contains more documents than WoS $(n=\mathbf{4 1 4 5})$. In addition, Scopus (since 1936) has longer chronological framework of publication coverage, as compared to WoS (since 1988).

The growth of Open Access (OA) documents in both databases, starting from 2000, is also indicative. However, from 2010 to 2015 inclusive, WoS database $(\mathrm{n}=\mathbf{2 3 7})$ includes more OA documents than Scopus ( $\mathrm{n}=98$ ). But the period 2016-01.06.2020 already demonstrates a slight dominance of the OA publications number in Scopus $(n=192)$ as compared to WoS $(n=185)$. In Table 1, the data obtained are highlighted in red for clarity.

Table 1. Publication activity analysis of LIS university researchers

\begin{tabular}{|c|c|c|c|c|c|}
\hline \multicolumn{2}{|c|}{ Scopus } & & \multicolumn{2}{c|}{ WoS (CC) } \\
\hline & $1936-2020$ & $\begin{array}{c}2016- \\
01.06 .2020\end{array}$ & & $1988-2020$ & $\mathbf{2 0 1 6 - 0 1 . 0 6 . 2 0 2 0}$ \\
\hline & Total & Total & & Total & Total \\
& documents - & documents - & 1090 & 4145 & 1297 \\
& 4561 & 10 documents - & & \\
\hline
\end{tabular}


THE CONTRIBUTION OF THEORY AND RESEARCH TO THE TRANSFORMATION OF LIBRARIES

\begin{tabular}{|c|c|c|c|c|c|c|c|c|}
\hline \multirow{3}{*}{ Year } & \multicolumn{2}{|c|}{ Access type } & \multicolumn{2}{|c|}{ Access type } & \multicolumn{2}{|c|}{ Access type } & \multicolumn{2}{|c|}{ Access type } \\
\hline & \begin{tabular}{|l|} 
Open \\
Access
\end{tabular} & Other & $\begin{array}{l}\text { Open } \\
\text { Access }\end{array}$ & Other & $\begin{array}{l}\text { Open } \\
\text { Access }\end{array}$ & Other & $\begin{array}{l}\text { Open } \\
\text { Access }\end{array}$ & Other \\
\hline & 365 & 4196 & 192 & 898 & 496 & 3649 & 185 & 1112 \\
\hline 2020 & - & - & 12 & 41 & - & - & 4 & 21 \\
\hline 2019 & - & - & 64 & 240 & - & - & 39 & 187 \\
\hline 2018 & - & - & 48 & 233 & - & - & 35 & 299 \\
\hline 2017 & - & - & 45 & 206 & - & - & 46 & 300 \\
\hline 2016 & - & - & 23 & 178 & - & - & 61 & 305 \\
\hline 2015 & 23 & 171 & & & 95 & 327 & & \\
\hline 2014 & 29 & 216 & & & 71 & 267 & & \\
\hline 2013 & 9 & 234 & & & 18 & 233 & & \\
\hline 2012 & 9 & 179 & & & 30 & 219 & & \\
\hline 2011 & 17 & 236 & & & 11 & 186 & & \\
\hline 2010 & 11 & 249 & & & 12 & 209 & & \\
\hline ........ & & $\ldots \ldots$ & & & & & & \\
\hline 2001 & 3 & 81 & & & 2 & 58 & & \\
\hline 2000 & 0 & 49 & & & 1 & 106 & & \\
\hline
\end{tabular}

Distribution analysis of the documents presented by knowledge areas in both of the databases reveals aspects of the university library activity in the context of the following top 6 areas:

- Scopus - Computer Science, Engineering, Social Sciences, Mathematics, Physics and Astronomy, Medicine;

- WoS (CC) - Information Science and Library Science, Education Educational Research, Computer Science, Engineering Electrical Electronic, Social Sciences, Management.

Analysis of publication activity was carried out with distributions by author, university, country, knowledge areas using the keywords "university library" AND "academic library."

Scopus. Search results - 54 conference papers (Open Access - 5, Other - 49). Of these, 37 works for the period 2010-2018, 17 works for the period 1984-2009. It should be noted that in 2019 and 2020 (as of 01.06.) not a single paper was indexed in Scopus. In 2018 - 6 works, in 2017 $-2,2016-2$. 
Four authors each have two publications: Liu, L. (Chongqing Jiaotong University, Chongqing, China); Pan, W. (Shanghai Jiao Tong University, Shanghai, China); Saludin, M.N. (Sultan Idris Pendidikan University, Tanjong Malim, Malaysia); and Zheng, Q. (Shanghai Jiao Tong University, Shanghai, China).

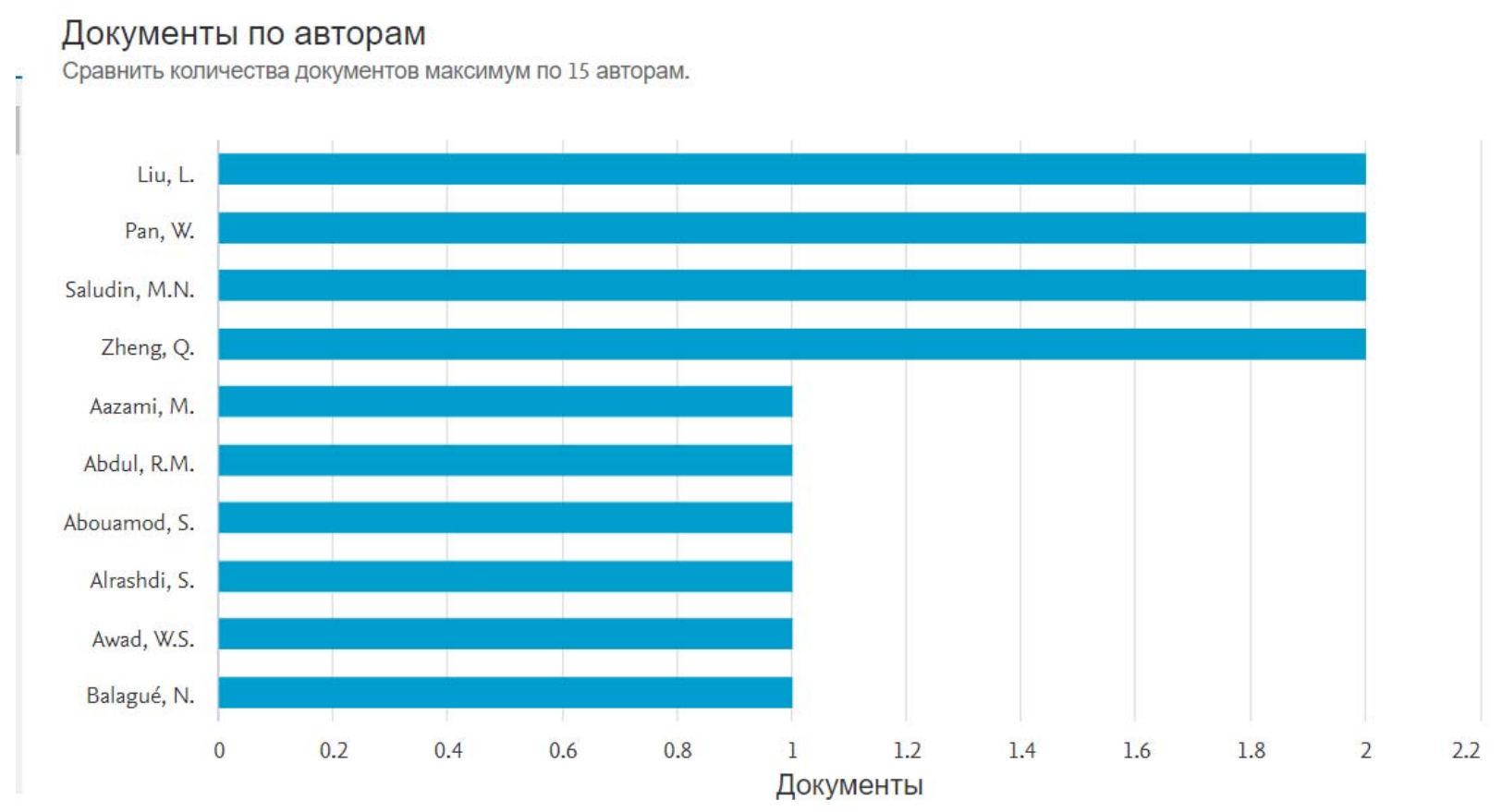

The remaining 46 authors have one publication each. They represent the following universities respectively: Kansas State University, Sorbonne Universite, Universiti Kebangsaan Malaysia, East West University, Universiti Tenaga Nasional, University of Zagreb, Purdue University, Monash University, Universidad de León, University of Liverpool, University of Library Studies and Information Technologies, University of Botswana, University of New South Wales UNSW Australia, Freie Universität Berlin and others.

Analysis of publication activity by country allows determining the top 10 . These are the following countries: United States (10), China (9), Australia (4), Malaysia (3), Spain (3), United Kingdom (3), Bangladesh (2), Croatia (2), India (2), and Iran (2).

Results of publication activity of authors from Eastern Europe countries were clarified by searching and quantitative analysis of publications in 10 countries. Chronological framework was 2016-01.06.2020. Total publications found in Scopus are 153 "conference papers" and in WoS (CC) - 207 "proceedings papers." At the same time, the author has not found documents of the authors of the Republic of Belarus in any of the databases (Table 2).

Table 2. Eastern Europe countries whose publications are presented in Scopus and WoS databases (2016-01.06.2020)

\begin{tabular}{|l|l|l|}
\hline Countries of Eastern Europe & Scopus & WoS (CC) \\
\hline Czech Republic & 18 & 10 \\
\hline
\end{tabular}


University Library at a New Stage of Social Communications Development. Conference Proceedings, 2020, No V

THE CONTRIBUTION OF THEORY AND RESEARCH TO THE TRANSFORMATION OF LIBRARIES

\begin{tabular}{|l|l|l|}
\hline Russian Federation & 38 & 31 \\
\hline Poland & 23 & 15 \\
\hline Romania & 18 & 61 \\
\hline Ukraine & 13 & 7 \\
\hline Slovakia & 7 & 8 \\
\hline Bulgaria & 18 & 69 \\
\hline Hungary & 18 & 5 \\
\hline Republic of Moldova & 0 & 1 \\
\hline Republic of Belarus & 0 & 0 \\
\hline Total & 153 & 207 \\
\hline
\end{tabular}

Distribution analysis of the documents presented by knowledge areas in both of the databases reveals aspects of the university library's activity in the context of the following top 6 areas:

- Scopus - Computer Science, Engineering, Social Sciences, Mathematics, Physics and

Astronomy, Medicine;

- WoS (CC) - Information Science and Library Science, Education Educational Research, Computer Science, Engineering Electrical Electronic, Social Sciences, Management

Citation analysis using the keywords "university library" AND "academic library."

As a result of the documents search, 54 conference papers were found in the Scopus database. The date range is for the entire indexing time.

Top 10 of the most cited authors and their works:

1) McKay, D., Hinze, A., Heese, R., Vanderschantz, N., Timpany, C., Cunningham, S. J. (2012). An exploration of ebook selection behavior in academic library collections. Affiliation Library, Swinburne Institute, Australia; Dept. of Computer Science, University of Waikato, New Zealand, Australia; Institute of Computer Science, Freie Universität Berlin, Berlin, Germany, respectively. 18 citations (2012-2019).

2) Daneshgar, F., \& Parirokh, M. (2007). A knowledge schema for organisational learning in academic libraries. Affiliation - School of Information Systems, Technology and Management, UNSW, Sydney, Australia; Ferdowsi University of Mashad, Iran; School of Information Systems, Technology and Management, UNSW, Sydney, Australia, respectively. 15 citations (2007-2018).

3) Jain, P. (2013). Knowledge management in academic libraries and information centres: A case of university libraries. Affiliation - Department of Library and Information Studies, University of Botswana Gaborone, Botswana, respectively. 9 citations (2014-2019).

4) Oppenheim, C., \& Stuart D. (2004). Is there a correlation between investment in an academic library and a higher education institution's ratings in the research assessment exercise? Affiliation - Department of Information Science, Loughborough University, Loughborough, United Kingdom, respectively. 9 citations (2005-2020). 
5) Rogers, A., Leduc-Mills, B., O'Connell, B. C., \& Huang, B. (2015). Lending a hand: Supporting the maker movement in academic libraries. Affiliation - North Carolina State University Libraries, United States; SparkFun Electronics, Inc., Education Department, United States; Smith College Libraries, Northampton, MA, United States, respectively. 7 citations (20172020).

6) Calvi, L., Cassella, M., \& Nuijten, K. (2010). Enhancing users' experience: A content analysis of 12 university libraries facebook profiles. Affiliation - NHTV, University of Applied Science, Academy for Digital Entertainment, Breda, Netherlands; Università di Torino, Torino, Italy, respectively. 7 citations (2010-2019).

7) Chen, Y.-H. (2011). Undergraduates' perceptions and use of the University Libraries Web portal: Can information literacy instruction make a difference? Affiliation - University at Albany Libraries, State University of New York, University Library LI-304; Albany, NY, United States, respectively. 6 citations (2011-2019).

8) Rubinić, D., Stričević, I., \& Juric, M. (2013). Information Literacy Course? The Perception of Students and Professors: University of Zadar Case. Affiliation - University Library, University of Zadar, Zadar, Croatia; Department of Information Sciences, University of Zadar, Zadar, Croatia, respectively. 5 citations (2016-2019).

9) Retnani, W. E., Prasetyo, B., Prayogi, Y. P., Nizar, M. A., \& Abdul, R. M. (2018). Usability testing to evaluate the library's academic web site. Affiliation - Software Engineering Laboratory, Computer Science Program, University of Jember, Jember, Indonesia, respectively. 4 citations (2018-2020).

10) Devlin, F. A., Burich, N. J., Stockham, M. G., Summey, T. P., \& Turtle, E. C. (2006). Getting beyond institutional cultures: When rivals collaborate. Affiliation - University of Kansas, United States; Kansas State University, United States; Emporia State University, United States, respectively. 4 citations (until 2016).

As a result of the document search, 33 proceedings papers were found in Web of Science database. The date range is for the entire indexing time.

Top 10 of the most cited authors and their works:

1) Berk, J., Olsen, S., Atkinson, J. et al. (2007). Innovation in a podshell: bringing information literacy into the world of podcasting. Affiliation - Curtin University, Australia, respectively. 9 citations (2007-2016).

2) Sitthisomjin, J., Chaiwan, J., Rongraung, S. et al. (2014). Soft skills for University Library Staff in Thailand. Affiliation - Khon Kaen University, Thailand, respectively. 6 citations (20142020).

3) Lee, H. (2001). Networked collections in question: An exploratory study. Affiliation University of Wisconsin, USA, respectively. 6 citations (2002-2008).

4) Abramson, A. D. (1998). Monitoring and evaluating use of the World Wide Web in an academic library: An exploratory study. Affiliation - American University, USA, respectively. 6 citations (1998-2006).

5) Duplicate metadata from a previous article by Abramson, A. D.

6) Warwick, C. (2016). Beauty is truth: Multi-sensory input and the challenge of designing aesthetically pleasing digital resources. Affiliation - Durham University, England, respectively. 2 citations (2019-2020).

7) Hung, W.-H., ChanLin, L.-J. (2015). Development of Mobile Web for the Library. Affiliation - Fu Jen Catholic University, Taiwan, respectively. 2 citations (2018-2019) 
8) Tomescu, Silvia-Adriana. (2018). Blended Learning Methodology for Library Professionals "Carol I" Central University Library. Affiliation - Carol I Cent. University, Romania, respectively. 1 citation (2020)

9) Kian, T. P., Suradi, Nur R. M., \& Saludin, M. N. (2012). The Impact of Complaint Management and Service Quality on Organizational Image: A Case Study at the Malaysian Public University Library. Affiliation - University Kebangsaan Malaysia, Malaysia, respectively. 1 citation (2014).

10) Young, H., Lund, P., \& Walton, G. (2009). Tools to Develop Effective Research Support in an Academic Library: A Case Study. Affiliation - Loughborough University, England, respectively. 1 citation (2019).

\section{Conclusions}

Comparative analysis of Scopus and Web of Science (CC) databases, covering the "conference paper"/"proceedings paper" publication type for all the years of their reflection in each of the databases, as well as in the chronological framework 2016-01.06.2020 yielded interesting results.

1. Publication activity analysis of the university (academic) LIS researchers shows that Scopus ( $\mathrm{n}=4561)$ represents more documents than WoS database $(n=4145)$;

2. The growth of Open Access (OA) documents in both databases, starting from 2000, is indicative. But the period 2016-01.06.2020 demonstrates a slight dominance of the number of OA publications in Scopus ( $\mathrm{n}=192)$ compared to $\mathrm{WoS}(\mathrm{n}=185)$.

3. The obtained results of the publication activity analysis also concerned the distribution by authors, universities, countries, and knowledge areas. For example, papers by authors from Eastern European countries, presented in Scopus and WoS databases (2016-01.06.2020), reflect the following publication activity: Poland $(n=23 / n=15)$, Romania $(n=18 / n=61)$, Ukraine $(n=13 / n=7)$, Slovakia $(\mathrm{n}=7 / \mathrm{n}=8)$, Bulgaria $(\mathrm{n}=18 / \mathrm{n}=69)$, etc.

4. Citation analysis using the keywords "university library" AND "academic library" shows that the most cited conference paper in Scopus (published in 2018) has 18 citations. The most cited proceedings paper in Web of Science database (published in 2007) has 9 citations. Of course, these are poor results, which may be caused by the conference focus on the rapidly changing subjects.

5. Showing a relatively low LIS coverage by the university researches, as well as their law citation rate, the work demonstrates that LIS researchers/practitioners need to create more quality publications to be recognized as an important area.

6. The results of this study can serve as a roadmap for LIS researchers to help them continue their work under conditions of rapid transformation of the library science.

The author hopes that this work will generate great research interest in the field of LIS and understanding the great value of Conference proceeding as a publication containing original/primary research results.

\section{REFERENCES}

Agarwal, N. K., \& Islam, M. A. (2018). Ascertaining the place of Library \& Information Science in Knowledge Management research. Proceedings of the 81st Annual Meeting of the Association for Information Science \& Technology, Vancouver, Canada, November, 55(1), 9-14, 2018. https://doi.org/10.1002/pra2.2018.14505501002 (in English) 
Ahmad, K., JianMing, Z., \& Rafi, M. (2019). Assessing the literature of knowledge management (KM) in the field of library and information science. Information Discovery and Delivery, 47(1), 35-41. doi: https://doi.org/10.1108/IDD-06-2018-0021 (in English)

Anwar, M. A., \& Saeed, H. (1999). Pakistani librarians as authors: a bibliometric study of citations in LISAPLUS. Asian Libraries, 8(2), 39-46. doi: https://doi.org/10.1108/10176749910257623 (in English)

Borrego, Á., Ardanuy, J., \& Urbano, C. (2018). Librarians as Research Partners: Their Contribution to the Scholarly Endeavour Beyond. Library and Information Science, 44(5), 663-670. doi: https://doi.org/10.1016/j.acalib.2018.07.012 (in English)

Borrego, Á., \& Pinfield, S. (2020). Librarians publishing in partnership with other researchers: Roles, motivations, benefits, and challenges. Portal: Libraries and the Academy, 20(4). 655-675. doi: https://doi.org/10.1353/pla.2020.0031 (in English)

Dash, N. K., Sahoo, J., \& Mohanty, B. (2015). Evolution of Library Assessment Literature - A Bibliometric Analysis of LAC Proceedings. Innovative Librarianship: Adapting to Digital Realitiesin Proceedings of 10th International CALIBER - 2015, March 12-14, HP University, IIAS, Shimla and INFLIBNET Centre, Himachal Pradesh, India, 91-106. Retrieved from https://www.researchgate.net/publication/275644489_Evolution_of_Library_Assessment_Literat ure A Bibliometric Analysis of LAC Proceedings (in English)

De Sutter, B., \& Van Den Oord, A. (2012). To be or not to be cited in computer science. Communcations of the ACM, 55(8), 6975. doi: https://doi.org/10.1145/2240236.2240256 (in English)

González-Albo, B., \& Bordons, M. (2011). Articles vs. proceedings papers: Do they differ in research relevance and impact? A case study in the Library and Information Science field. Journal of Informetrics, 5(3), 369-381. doi: https://doi.org/10.1016/j.joi.2011.01.011 (in English)

Erfanmanesh, M. A., Didegah, F., \& Omidvar, S. (2010). Research productivity and impact of library and information science in the Web of Science. Malaysian Journal of Library \& Information Science, 15(3), 85-95. Retrieved from https://mjlis.um.edu.my/article/view/6944 (in English)

IOPScience. (2020). Proceedings policy on Impact Factors. Retrieved from https://publishingsupport.iopscience.iop.org/questions/proceedings-policy-on-impact-factor/ (in English)

Jabeen, M., Yun, L., Rafiq, M., \& Jabeen, M. (2015). Research productivity of library scholars: bibliometric analysis of growth and trends of LIS publications". New Library World, 116(7-8), 433-454. doi: http://dx.doi.org/10.1108/NLW-11-2014-0132 (in English)

Jokić, M (2020). Productivity, visibility, authorship, and collaboration in library and information science journals: Central and Eastern European authors. Scientometrics, 122(2), 1189-1219. doi: https://doi.org/10.1007/s11192-019-03308-4 (in English)

Kolesnykova, T., Matveyeva, O., Manashkin, L., \& Mìshchenko, M. (2019). Railway transportation of dangerous goods: a bibliometric aspect. MATEC Web of Conferences, 294, 03014. EOT-2019. doi: https://doi.org/10.1051/matecconf/201929403014 (in English)

Kolesnykova, T. O., Pominova, O. V., \& Kolesnykov, S. R. (2016). Obtaining of new knowledge in concerning «air conditioning» at the railway transport: scientometric aspect. Science and Transport Progress, 3(63), 7-19. doi: http://dx.doi.org/10.15802/stp2016/74708 (in Ukranian)

Lisée, C., Larivière, V., \& Archambault, E. (2008). Conference proceedings as a source of scientific information: A bibliometric analysis. Journal of the American Society for Information Science and Technology, 59(11), 1776-1784. Retrieved from https://www.researchgate.net/publication/220432712_Conference_proceedings_as_a_source_of_s cientific information A bibliometric analysis (in English) 
КОЛЕСНИКОВА Т. О.

Науково-технічна бібліотека, Дніпровський національний університет залізничного

транспорту імені академіка В. Лазаряна (Дніпро, Україна),

e-mail: chief.library@gmail.com, ORCID 0000-0002-4603-4375

\section{ЧАС КОНФЕРЕНЦЙ В БІБЛІОТЕЧНО-ІНФОРМАЦЙНИХ НАУКАХ. ЧАСТИНА 2: АНАЛІЗ ПУБЛІКАЦІЙНОЇ АКТИВНОСТІ ТА ЦИТУВАННЯ}

Мета. Друга частина дослідження "Conference time in the library and information sciences” спрямована на проведення бібліометричного аналізу публікаційної активності та цитованості авторів з бібліотекознавства та інформатики (LIS), які представляють свої документи на міжнародних конференціях, індексованих в Scopus i/aбo Web of Science (CC). Методи. Бібліометричний аналіз публікацій, які є Conference proceeding ("proceedings paper" i / або "conference paper"), був проведений з використанням даних баз цитування Scopus i Web of Science (CC). За допомогою компаративного аналізу вивчені отримані дані, що охоплюють тип публікації "conference paper" / "proceedings paper" за всі роки їх відображення в кожній з баз, а також додатково в хронологічних рамках 32016 р. по 01.06 .2020 р. Результат. Аналіз публікаційної активності університетських (академічних) дослідників LIS показує, що в БД Scopus (n = 4561) представлено більшу кількість документів, ніж в БД $\operatorname{WoS}(\mathrm{n}=4145)$. Показовим є зростання документів відкритого доступу $(\mathrm{OA})$ в обох БД, починаючи з 2000 р. Але період 2016 - 01.06.2020 pр. демонструє незначне домінування кількості публікацій OA в Scopus $(\mathrm{n}=192)$ в порівнянні з $\mathrm{WoS}(\mathrm{n}=185)$. Також отримано дані розподілу за авторами, університетами, країнами, галузями знань. Аналіз цитування показує невисокі результати по обох базах, причиною яких може бути зосередженість конференцій на швидко мінливих темах. Висновки. Показуючи відносно низьке охоплення LIS в дослідженнях університетських вчених, а також невисокий рівень їх цитування, дана робота демонструє, що дослідникам / практикам LIS необхідно створювати більше якісних публікацій, щоб їх визнали важливою областю. У автора є надія, що ця робота викличе великий дослідницький інтерес в області LIS і розуміння великої цінності Conference proceeding як видання, що містить оригінальні / первинні результати досліджень.

Ключові слова: бібліотекознавство та інформатика; конференція; conference proceeding; proceedings paper; conference paper; університетська бібліотека; публікаційна активність; бібліометричний аналіз; цитування 